\title{
Theoretical and perceived balance of power inside Spanish public hospitals Paloma Salvadores ${ }^{1}$, José Schneider ${ }^{* 1}$ and Imanol Zubero ${ }^{2}$
}

Address: ${ }^{1}$ Universidad Rey Juan Carlos, Facultad de Ciencias de la Salud, Madrid, Spain and ${ }^{2}$ Universidad del País Vasco, Facultad de Sociología y Ciencias Políticas, Bilbao, Spain

E-mail: Paloma Salvadores - p.salvadores@cs.urjc.es; José Schneider* - schneider@teleline.es; Imanol Zubero - cipzubei@lg.ehu.es *Corresponding author

Published: 4 September 2001

BMC Health Services Research 2001, 1:9
Received: I August 200 I

Accepted: 4 September 200I

This article is available from: http://www.biomedcentral.com/1472-6963///9

(c) 200I Salvadores et al; licensee BioMed Central Ltd. Verbatim copying and redistribution of this article are permitted in any medium for any noncommercial purpose, provided this notice is preserved along with the article's original URL. For commercial use, contact info@biomedcentral.com

\begin{abstract}
Background: The hierarchical pyramid inside Spanish public hospitals was radically changed by the Health Reform Law promulgated in 1986. According to it, the manpower of the hospitals was divided into three divisions (Medical, Nursing, General Services/Administration), which from then on occupied the same level, only subject to the general manager. Ten years after the implementation of the law, the present study was designed in order to investigate if the legal changes had indeed produced a real change in the balance of power inside the hospitals, as perceived by the different workers within them.
\end{abstract}

Materials and Methods: A questionnaire was administered to I,027 workers from four different public hospitals (two university-based and two district hospitals). The participants belonged to all divisions, and to all three operative levels (staff, supervisory and managerial) within them. The questionnaire inquired about the perceived power inside each division and hierarchical level, as well as about that of the other divisions and hierarchical levels.

Results: Every division attributed the least power to itself. The Nursing and the Administrative division attributed the highest power to the physicians, and these attributed the highest power to the General Services/Administrative division.

All hierarchical levels (including the formal top of the pyramid) attributed significantly more power to the other than to them.

Conclusions: More than ten years after the implementation of the new law, the majority of workers still perceive that the real power within the hospitals is held by the physicians (whereas these feel that it has shifted to the administrators). No division or hierarchical level believes it holds any significant degree of power, and this carries with it the danger of also not accepting any responsibility.

\section{Introduction}

The Spanish population is covered almost completely (98.5\%) by a National Health Service. In the Basque provinces, in the north of the country, this coverage is 99.7\% [1]. One of the three provinces (Vizcaya) has two University-based public tertiary care referral centres, the 
other two (Guipuzcoa and Alava) having each a University-associated hospital of similar characteristics. The public hospital scheme is completed by a web of district hospitals, such that each so-called "Health Area", covering a population of 150,000 to 200,000 , is served by a hospital and its associated outpatients clinics (called "ambulatories" or "Health Centres") [2].

In 1987 [3], the hierarchy inside the Spanish public hospitals was completely restructured by a series of decrees regulating the Health Reform Law of 1986 [4], promulgated by the Socialist Government then in power. According to the new structure of "shared management", there was no hierarchical predominance of any of the three divisions composing the hospital staff (Medical, Nursing and Admnistrative and Service Division) over the other. All of them were subject, on an equal level, to the general manager (Fig. 1). Each division, in its turn, was divided into three operational levels: managerial (Medical Director, Matron, Administrative Director, etc.); supervisory (chairpersons of the different clinical departments, Nursing supervisors, heads of technical staff, etc.); and finally the staff level, composed by the overwhelming majority of the workers. [5].

The general objective behind this reform was to make each division, having different (albeit interrelated) tasks, fully responsible for the decisions to be taken within it. This should result in a more dynamic fuctioning of the hospital, breaking, at the same time, with the almost exclusively physician-centered working scheme up to then in use. By eliminating the traditional predominance of the medical division over the remaining ones of the hospital, putting them all on an equal level, it was hoped that a more collaborative working environment would emerge, to the general satisfaction of everyone involved.

The present study was designed in 1997, ten years after the reform had been put into practice in the hospitals. It was carried out in order to evaluate whether the new formal organization of the hospitals had resulted in a real shift of the balance of power within them, and in a general feeling of being involved in their management, as perceived by the workers belonging to all divisions, and to all operational levels.

\section{Materials and Methods}

The participating workers were individually asked to fill out a simple questionnaire (Fig. 2) in the presence of the interviewer, and within the shortest time (less than 2 minutes), in order to prevent "rethinking" of the posed questions to interfere with the immediate feelings about them by the participants.
Table I: Distribution of interviwed workers by participating centres

\begin{tabular}{lcc}
\hline Centre & Frequency & Percentage \\
\hline & & \\
Basurto University Hospital & 360 & $35.1 \%$ \\
Cruces University Hospital & 330 & $32.1 \%$ \\
Galdacano District Hospital & 209 & $20.4 \%$ \\
Zumarraga District Hospital & 128 & $12.5 \%$ \\
TOTAL & $\mathbf{1 , 0 2 7}$ & $\mathbf{1 0 0 . 0 \%}$ \\
\end{tabular}

In all, 1,027 workers from two tertiary care, Universitybased referral hospitals (Hospital de Cruces and Hospital de Basurto, both at Bilbao) and two district hospitals (Galdácano and Zumárraga) situated in two out of thethree Basque provinces (Vizcaya and Guipuzcoa) answered the questionnaire (Table 1). The number was higher for the University hospitals, but this merely reflects their larger staff. The distribution according to the different divisions is given in Table 2, and is also well balanced, in agreement with the respective density of each population inside the different hospitals. Accordingly, the highest number of answered questionnaires comes from the staff level, followed by the supervisory and the managerial hierarchical level (Table 3). The different posts occupied by the interviewed participants are displayed in Table 4.

Table 2: Distribution of interviewed workers according to the different divisions

\begin{tabular}{lcc}
\hline Division & Frequency & Percentage \\
\hline Nursing & & \\
Medical & 656 & $63.9 \%$ \\
General Services & 187 & $18.2 \%$ \\
and Administration & & \\
TOTAL & 182 & $17.7 \%$ \\
& 1,027 & $100.0 \%$
\end{tabular}

Since we anticipated that many of the interviewed workers would not be able to distinguish immediately between the two questions posed (the first, addressing "power", understood as the ability to take decisions independently, the second addressing "participation", understood as the involvement in decisions affecting the whole organisation), two standard answers were prepared for the interviewers to the question of what was meant under "power" and "participation": 


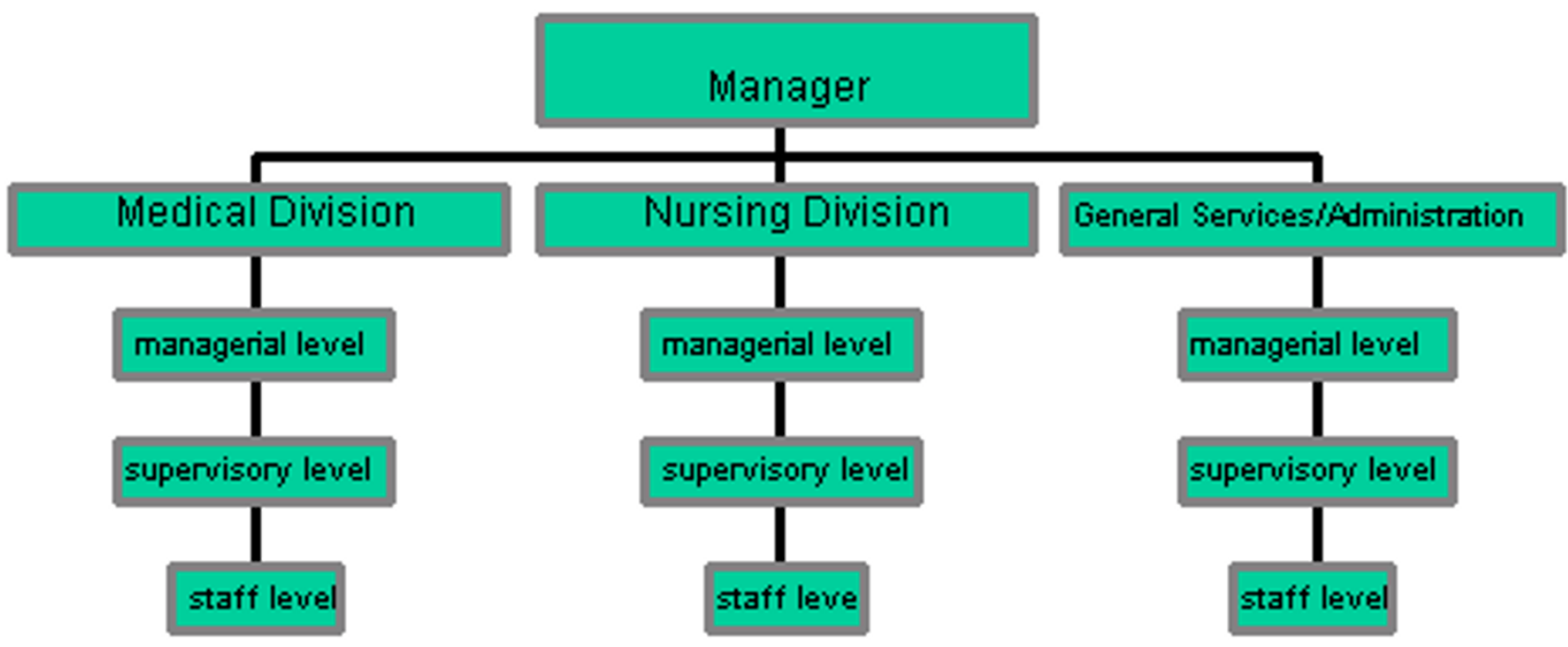

Figure I

Official hierarchical pyramid of Spanish public hospitals

"Power": "To which degree can decisions be taken independently within your hierarchical level, without asking the other ones?"

"Participation": "How often is your hierarchical level asked, when a decision potentially affecting the hospital is taken at another level?"

We were interested in discriminating between these two aspects, because the new (and much publicised) philosophy of "shared management" stated that everyone inside the organisation would have a saying in questions affecting the whole collective, independently of her/his hierarchical level. It was thus possible, in theory, for a subordinate level not to be able to take an independent decision regarding, .e.g., which technological equipment to purchase in a given area (lack of "power"), but to be asked nevertheless about its preferences or priorities regarding the matter ("participation").

Table 3: Number of answered questionnaires by hierarchical level

\begin{tabular}{lcc}
\hline Hierarchical level & Frequency & Percentage \\
\hline Staff & & \\
Supervisory & 871 & $84.8 \%$ \\
Managerial & 113 & $11.0 \%$ \\
TOTAL & 43 & $4.2 \%$ \\
& 1,027 & $100.0 \%$ \\
\hline
\end{tabular}

The statistical analysis of the studied variables was performed by means of the chi-square test for trend, using the GraphPad Prism statistical package (GraphPad Software, Inc., San Diego, CA, U.S.A.). Differences were considered significant, when $\mathrm{p}$ was $<0.05$.

Table 4: Posts occupied by the workers having answered the questionnaire

\begin{tabular}{lcc}
\hline Post & Frequency & Percentage \\
\hline & & \\
Physician & 142 & $13.8 \%$ \\
Nurse & 300 & $29.2 \%$ \\
Female nurse aid & 276 & $26.9 \%$ \\
Male nurse aid & 59 & $5.7 \%$ \\
Secretarial staff & 51 & $5.0 \%$ \\
Technical staff & 43 & $4.2 \%$ \\
Medical chairperson & 36 & $3.5 \%$ \\
Nursing supervisor & 60 & $5.8 \%$ \\
Chief of personnel & 15 & $1.5 \%$ \\
Head of technical staff & 2 & $0.2 \%$ \\
Medical Director & 9 & $0.9 \%$ \\
Matron & 20 & $1.9 \%$ \\
Administrative Director & 12 & $1.2 \%$ \\
General manager & 2 & $0.2 \%$ \\
TOTAL & 1,027 & $100 \%$ \\
& & \\
\hline
\end{tabular}


WE WOULD BE EXTREMELY GRATEFUL IF YOU COULD ANSWER THE FOLLOWING QUESTIONS

Hospital

Position held

Age $\quad$ Man $\square \quad$ Woman $\square$

I. PLEASE IDENTIFY YOUR HIERARCHICAL LEVEL AND SCORE THE POWER (INDEPENDENT DECISION-TAKING) YOU THINK IT HAS INSIDE THE HOSPITAL.. THEN SCORE THE POWER THE OTHER LEVELS HAVE

$\begin{array}{llllll}\text { OPERATIVE (STAFF) LEVEL } & 1 & 2 & 3 & 4 & 5 \\ \begin{array}{l}\text { SUPERVISORY LEVEL } \\ \text { (Chairperson, Head of Staff, }\end{array} & 1 & 2 & 3 & 4 & 5 \\ \begin{array}{l}\text { Supervisor...) } \\ \begin{array}{l}\text { MANAGEMENT LEVEL } \\ \text { (Manager, Medical Director, } \\ \text { Matron, Administrative Director...) }\end{array}\end{array} & 1 & 2 & 3 & 4 & 5\end{array}$

II. PLEASE SCORE THE DEGREE OF PARTICIPATION IN THE MANAGEMENT OF THE HOSPITAL YOUR HIERARCHICAL LEVEL HAS, AND THE DEGREE OF PARTICIPATION THE OTHER LEVELS HAVE

$\begin{array}{lccccc} & \text { none } & \text { little } & \text { moderate } & \text { considerable very much } \\ \text { OPERATIVE (STAFF) LEVEL } & 1 & 2 & 3 & 4 & 5 \\ \begin{array}{l}\text { SUPERVISORY LEVEL } \\ \text { (Chairperson, Head of Staff, }\end{array} & 1 & 2 & 3 & 4 & 5 \\ \begin{array}{l}\text { Supervisor...) } \\ \begin{array}{l}\text { MANAGEMENT LEVEL } \\ \text { (Manager, Medical Director, } \\ \text { Matron, Administrative Director...) }\end{array}\end{array} & 1 & 2 & 3 & 4 & 5\end{array}$

III. WHICH DIVISION DO YOU THINK HAS THE GREATEST DEGREE OF POWER AND PARTICIPATION INSIDE THE HOSPITAL

MEDICAL $\square \quad$ NURSING $\square \quad$ GEN.SERVICES/ADMINISTRATION $\square \quad$ ALL EQUAL

Figure 2

Questionnaire answered by participants in the study 


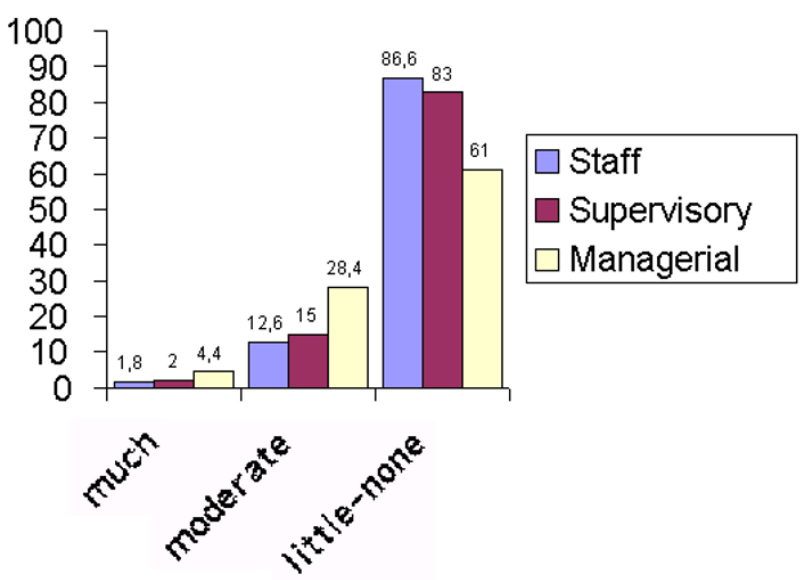

Figure 3

Power and participation attributed by each hierarchical level to itself. Chi-square test for trend: staff vs. mangerial, Chisquare $=10.33, p=0.0013$; staff vs. supervisory \& supervisory vs. managerial n.s.

\section{Results}

We evaluated 1,027 answered questionnaires. Compliance was above 90\%, and there were no significant differences in non-compliance between the different divisions or the different hierarchical levels.

The scores given by the interviewed workers were regrouped according to following scheme, in order to tabulate the results in a simplified manner: scores $1 \& 2=$ "little-none"; 3 = "moderate"; 4\&5 = "much"

There were virtually no differences in the score attributed by any given participant to questions 1 and 2, and after regrouping as stated above, these slight and infrequent differences disappeared altogether.

All hierarchical levels, irrespectively of the division to which they belonged, attributed significantly less power and participation in decision-taking to themselves, than to the rest (Figs. 3,4,5,6). This general result is not altered by the fact that there was a statistically significant difference in appreciation of the own power between the staff and the managerial level (Fig. 3), due to the latter attributing itself a moderate degree of power in $28.4 \%$ of instances (vs. 12.6\% for the staff). There was also a statistically significant difference in the appreciation of the relative power held by the supervisory level between the staff and the managerial level (Fig. 5).

The three different divisions of the hospitals attributed the least power to themselves, and significantly more power to the other. In the case of the Nursing and the

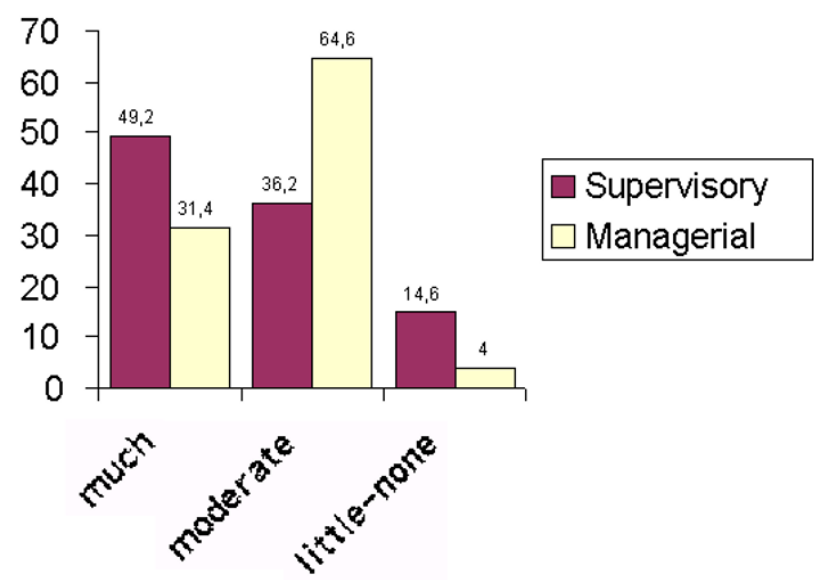

Figure 4

Power and participation attributed by the supervisory and managerial level to the staff. Chi-square test for trend: n.s.

General Services/Administrative division, the highest power was attributed to the physicians, whereas the latter attributed the highest power to the General Services/ Administrative division (Fig. 7).

\section{Discussion}

There were no differences in the scores given by the interviewed workers to questions 1 and 2 of the questionnaire. Thus, it appears that "power" and "participation" (or involvement in decision-taking) are interpreted by them as two faces of the same coin. This is not new. In two previous reports $[6,7]$, both physicians and nurses held a similar view.

It is also not surprising that, in our study, the other divisions of all hospitals unanimously felt that the medical division, still today, retains the highest degree of real power and influence on management decisions. Previous studies have arrived at basically the same conclusion $[8,9]$. Only one of them [8] holds a slightly more optimistic view. In it, Poole studied the power shifts in Dutch public hospitals after a series of changes in legislation very similar to those which took place in Spain (in fact, much of the Spanish legislation was inspired by the Dutch one). He arrived at the conclusion that "encouraging trends" are to be seen, especially regarding mid-level management. He states that physicians have lost some degree of power, at the expense of middle and top management. However, the whole report is permeated by the fact that, trends apart, Dutch hospitals are governed by what the author calls a "dual hierachy", constituted, on one side, by the formal administrative pyramid, and on the other one, by the professional medical system. This is exactly what the non-medical personnel of the hospitals 


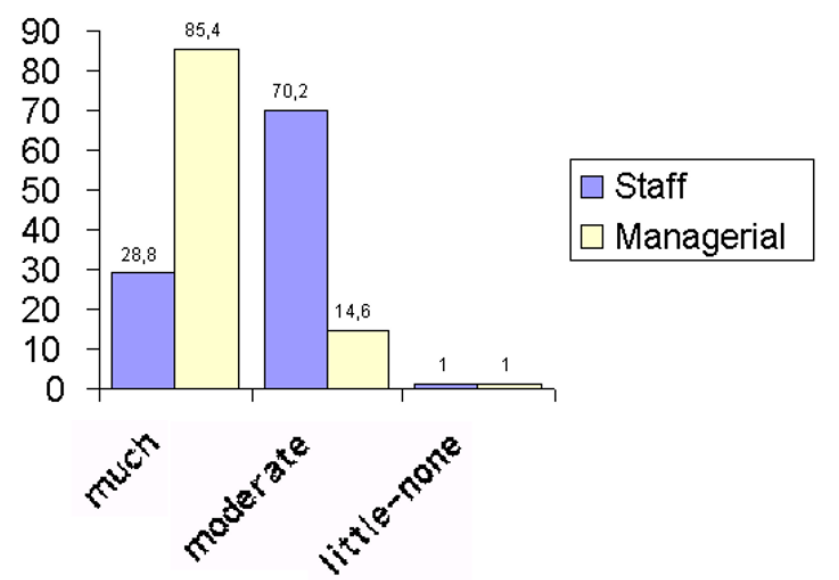

Figure 5

Power and participation attributed by the staff and managerial level to the supervisory level. Chi-square test for trend: Chi-square $=58.63, \mathrm{p}<0.000 \mathrm{I}$

studied by us perceives to be the reality, in spite of what the official administrative pyramid tries to tell them. It may be argued that the non-medical staff of every hospital is traditionally biased against the physicians (and this is certainly what the Spanish physicians think of the situation [10]), but the most striking study we are aware of on this subject tells us otherwise [11]. In it, young inpatients aged between 13 and 17 of a mental health unit, managed by a truly multidisciplinary team, were interviewed using both a questionnaire and person to person discussions, in order to know who they thought made the important decisions regarding their treatment and care. We can assume that such particular patients were not biased by a previous knowledge of questions regarding health politics, or in this case, the balance of power inside their hospital.

Nevertheless, they also unanimously felt that it was the physicians who made the important decisions, with the nurses lacking all authority and functioning as subordinate "all-rounders", to quote the exact definition used in the text. This is also in agreement with our own results: nurses and administrative staff regarded the medical staff as the holder of the highest real power inside the hospital, whereas the latter attributed the highest power to the administrative staff. However, all divisions (nurses included) agreed on one point: that it is the nurses who still hold the least power, in spite of the official claims to the contrary.

Another saddening result has emerged from our study. In fact, we have seen that no division, and no hierarchical level within it, seems to be willing to take any responsi-

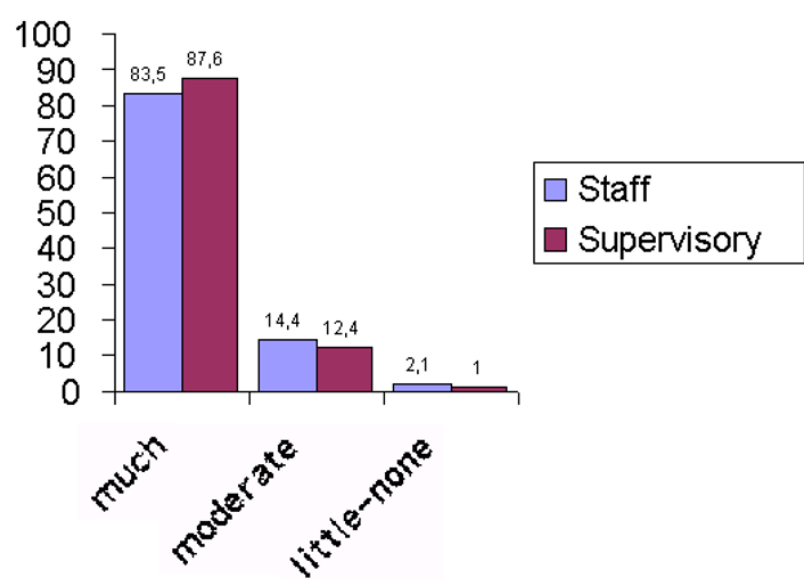

Figure 6

Power and participation attributed by the staff and supervisory level to the managerial level. Chi-square test for trend: n.s.

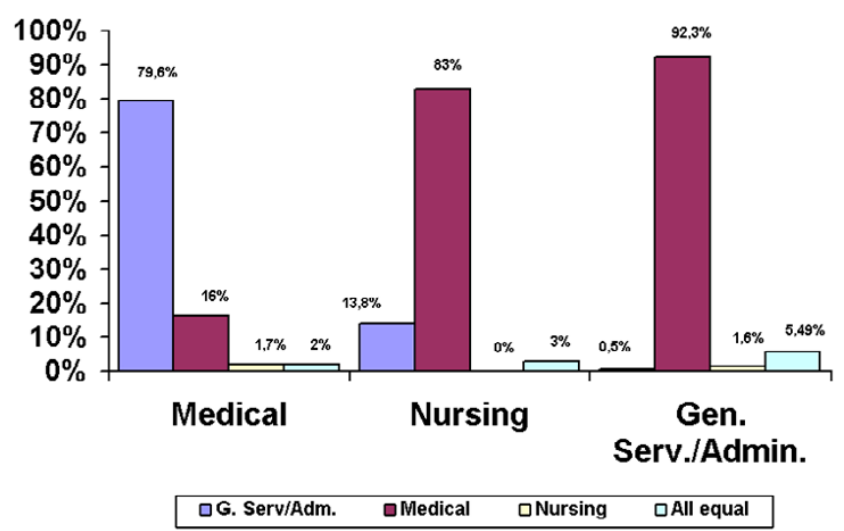

Figure 7

Power attributed to the remaining divisions of the hospital by each single one. $\mathrm{X}$-axis: the three different divisions of the hospital (Medical, Nursing, General Services and Administration). Y-axis: degree of power attributed to the other divisions. Chi-square test for trend: Medical vs. Nursing Division, Chi-square $=53.89, p<0.000 \mathrm{I} ;$ Medical vs. General Services/ Administrative Division, Chi-square $=78.83, \mathrm{P}<0.000 \mathrm{I}$; Nursing vs. General Services/Administrative Division, Chisquare $=7.94, p=0.0048$

bility in the management of their hospitals. Astonishingly, not even the highest strategic levels (managers, heads of departments, matrons, etc.) attribute real decisiontaking power to themselves, so that every division, and every level within it, feels that the power is in different hands than their own. Although the statistical analysis tells us that the managerial level has a significantly different view of the balance of power, this is mainly at the expense of $28.4 \%$ of its members admitting to have a 
moderate degree of it (vs. 12.6\% and $15.0 \%$ for the staff and supervisory level, respectively). In spite of the statistical significance, the striking fact is that $61.0 \%$ of the managerial staff claims to yield little or no power whatsoever, and that the percentage of those admitting to have much power is identical (and negligible) throughout all three levels. In such a context, where responsibility, and with it decision-taking is shifted from one level to the other by mere inhibition, it is not surprising that certain lasting situations, such as the much resented influence of the medical staff, are perpetuated. The implementation of a new law may change the distribution of formal power, but its balance will not change, unless informal power, which is perceived as the real one by the workers, is redistributed. This is unlikely to happen if, as indicated by our results, no one seems to be willing to accept his/her new responsibilities, and the loss of comfort associated with it. Perhaps this situation is just peculiar to the Spanish public hospitals, where, until recently, everyone held a lifetime job as a state employee. However, it must be noted that, in our study, there was a significant fraction of participants with ages below 35, especially from district hospitals, who are subject to a much more competitive form of contract (they are not civil servants with lifetime posts anymore), and there was no difference in the results if the different hospitals, or age groups, were compared with each other. It thus seems that similar studies would be worthwhile in other countries and within other health care systems, to see whether there are any differences between them and, if not, to look for possible solutions.

\section{Competing interests}

None declared

\section{References}

I. Departamento de Sanidad del Gobierno Vasco, Servicio Vasco de Salud: Osasuna Zainduz. Estrategias de Cambio para la Sanidad Vasca. Vitoria (Spain). Servicio Central de Publicaciones del Gobierno Vasco 1993

2. Osakidetza-Servicio Vasco de Salud: Memoria 1993. Vitoria (Spain) 1994

3. Real Decreto que establece el reglamento sobre estructura, organización y funcionamiento de los hospitales gestionados por el Instituto Nacional de la Salud. Boletín Oficial del Estado, 1987

4. Ley 14/86 General de Sanidad. Boletín Oficial del Estado, 1986

5. Sánchez-Caro J: Régimen jurídico de las nuevas fomas de gestión en la sanidad española (la perspectiva del Instituto Nacional de la Salud). Administración Sanitaria 2000, | 4:283-33|

6. Succi MJ, Lee SY, Alexander JA: Trust between managers and physicians in community hospitals. the effects of power over hospital decisions. J Healthc Manag 1998, 43:397-4I4

7. Empowerment and staff nurse decision involvement in nursing work environments: testing Kanter's theory of structural power in organizations. Res Nurs Health 1997, 20:341-352

8. Lameyer A: Machtverhältnisse im Krankenhaus. Pflege 2000, 1 3:227-233

9. Pool J: Hospital management: integrating the dual hierarchy? Int J Health Plann Manage 1991, 6:193-207

10. Amaya-Pombo C: La política sanitaria, desde la perspectiva de los médicos. Administración Sanitaria 2000, 15:29-35
II. Holyoake DD: Who's the boss? Children's perception of hospital hierarchy. Paediatr Nurs 1999, I I:33-36
Publish with BioMed Central and every scientist can read your work free of charge

"BioMedcentral will be the most significant development for disseminating the results of biomedical research in our lifetime." Paul Nurse, Director-General, Imperial Cancer Research Fund

Publish with BMC and your research papers will be:

- available free of charge to the entire biomedical community

- peer reviewed and published immediately upon acceptance

- cited in PubMed and archived on PubMed Central

- yours - you keep the copyright

Submit your manuscript here: BioMedcentral.com http://www.biomedcentral.com/manuscript/ editorial@biomedcentral.com 